\title{
Economic and Environmental Considerations for Zero-emission Transport and Thermal Energy Generation on an Energy Autonomous Island
}

\author{
Fontina Petrakopoulou $1,2^{*}$ \\ ${ }^{1}$ Thermal and Fluid Engineering Department, Universidad Carlos III de Madrid, Leganés (Madrid), SPAIN \\ ${ }^{2}$ Unit of Environmental Science and Technology, National Technical University of Athens, Athens, GREECE
}

*Corresponding Author: fpetrako@ing.uc3m.es

Citation: Petrakopoulou, F. (2018). Economic and Environmental Considerations for Zero-emission Transport and Thermal Energy Generation on an Energy Autonomous Island. European Journal of Sustainable Development Research, 2(1), 05. https://doi.org/10.20897/ejosdr/74299

Published: January 30, 2018

\begin{abstract}
The high cost and environmental impact of fossil-fuel energy generation in remote regions can make renewable energy applications more competitive than business-as-usual scenarios. Furthermore, energy and transport are two of the main sectors that significantly contribute to global greenhouse gas emissions. This paper focuses on the generation of thermal energy and the transport sector of a fossil fuel-based energy independent island in Greece. We evaluate (1) technologies for fully renewable thermal energy generation using building-specific solar thermal systems and (2) the replacement of the vehicle fleet of the island with electric and hydrogen-fueled vehicles. The analysis, based on economic and environmental criteria, shows that although solar thermal decreases greenhouse gases by $83 \%$, when compared to the current diesel-based situation, it only becomes economically attractive with subsidy scenarios equal to or higher than $50 \%$. However, in the transport sector, the sum of fuel and maintenance costs of fuel-cell and electric vehicles is found to be $45 \%$ lower than that of the current fleet, due to their approximately seven times lower fuel cost. Lastly, it will take approximately six years of use of the new vehicles to balance out the emissions of their manufacturing phase.
\end{abstract}

Keywords: energy independence, electric cars, fuel-cell cars, solar energy, hydrogen, thermal energy

\section{INTRODUCTION}

Fossil fuels are an integral part of numerous aspects of our lives with significant environmental consequences. The generation of electricity and thermal energy are responsible for $25 \%$ of the global greenhouse gas emissions (IPCC, 2014). Furthermore, the transport sector is associated with approximately $14 \%$ of the global greenhouse gas emissions and 22\% of the global carbon dioxide emissions (IPCC, 2014; United Nations, 2015). The expected population rise will unavoidably result in an increase of energy demand and vehicle use. Light-duty vehicles are predicted to increase significantly by 2050, which implies a strong increase in fuel consumption and pollution related to the transport sector (Tagliaferri et al., 2016). Alternative fuels and technologies to decrease the generated greenhouse gas emissions in the energy and transport sectors are widely studied.

Renewable energy sources present an alternative to the current fossil-fuel based status. However, their relatively high costs and intermittent operation makes their applications more demanding and complex. Regions without easy access to fossil fuels due to their remote location or costly conversion processes can constitute good application cases for renewable systems (Petrakopoulou, 2016). This study examines the case study of Skyros, a non-interconnected island in the Aegean Sea in Greece (Petrakopoulou, 2015b). The island is energy independent because it is not connected to the main electrical grid of Greece, but it relies heavily on the combustion of diesel. 
Table 1. Characteristics of solar thermal collectors available in the market

\begin{tabular}{llcc}
\hline Motion & Collector type & Concentration ratio & Temperature range $\left.{ }^{\circ} \mathbf{C}\right]$ \\
\hline \multirow{2}{*}{ Stationary } & Flat plate collector & 1 & $30-200$ \\
& Evacuated tube collector & 1 & $50-200$ \\
& Compound parabolic collector & $1-5$ & $60-300$ \\
\hline \multirow{2}{*}{ Single-axis tracking } & Linear Fresnel reflector & $10-40$ & $60-250$ \\
& Parabolic trough collector & $15-45$ & $50-400$ \\
& Cylindrical trough collector & $10-50$ & $60-300$ \\
\hline \multirow{2}{*}{ Two-axes tracking } & Parabolic dish reflector & $600-2,000$ & $100-1,500$ \\
& Heliostat field collector & $300-1,500$ & $150-2,000$ \\
\hline
\end{tabular}

We investigate (1) the substitution of the diesel-based space heating requirement of Skyros with solar energy systems and (2) the replacement of the vehicles of the island with zero emission vehicles.

Energy efficiency measures in buildings involve measures related to the building envelope (e.g., thermal insulation, reflective/green roofs), internal conditions (e.g., internal heat loads due to lighting and appliances) and building services systems (e.g., heating, ventilation). Thermal insulation is less effective in cooling-dominated buildings that have large internal heat loads in warmer climates and over-insulation that may increase energy requirements for space cooling should be avoided. Reflective/green roofs may present conflicting space requirements with other renewable energy technologies (e.g., photovoltaic, solar thermal water heaters and district heating/cooling) (Devabhaktuni et al., 2013; Grossmann et al., 2014; Hoppmann et al., 2014; Shi and Chew, 2012).

Solar thermal is very important in the residential sector. The thermal energy from a solar collector can be used in space heating, water heating, steam generation or stored in thermal storage for later use. Depending on solar intensity and location, it is expected that the cost of solar thermal energy will fall from 61-122 \$/MWh in 2007 to 22-44 \$/MWh in 2050 (Kamel and Fung, 2014). Some characteristics of solar thermal collectors based on their motion are shown in Table 1 (Allouhi et al., 2015). The storage tank is an important part of the solar water heating system, generally constructed using steel, concrete, plastic, fiber glass or other materials (Shukla et al., 2013). Phasechanging materials can reduce the thermal energy loss in either pipe or duct networks and the initial cost because they do not need insulation and storage tanks and thus save space (Sharif et al., 2015).

The proposed system in this work for the renewable thermal energy generation on Skyros includes vacuumtube solar collectors, geothermal energy only for water pre-heating purposes and radiant floors (Koroneos and Tsarouhis, 2012). The system includes a hot water storage tank.

While second-generation biofuels present an overall promising potential to decrease emissions in the transport sector, the biomass potential from the agricultural activities of Skyros is relatively low. A more suitable solution would be to generate biofuels from municipal organic waste, and more specifically, household food waste (Matsakas et al., 2014). Accounting for the fact that the quantity of food waste is continuously increasing, while its disposal causes environmental problems, such as greenhouse gas emissions and water contamination, its further utilization in energy applications becomes even more attractive. However, in addition to the fact that the utilization of food waste faces significant challenges related to technological and social issues, its composition varies significantly from place to place and resource to resource. To realize a representative study on waste utilization on Skyros the food waste composition must be first researched and examined in the lab in order to choose the appropriate technology for biofuel generation. For this reason, biomass-based applications in the transport sector are not considered here.

Alternatives for decreasing the greenhouse gas emissions in the transport sector include the use of biofuels in convectional vehicles and the introduction of electric or fuel-cell vehicles. Electric vehicles can be fully electric, hybrid or plug-in hybrid electric (Canals et al., 2016; Grandell et al., 2016). Fully electric cars have only an electric motor, while hybrid vehicles can run on both electric and conventional motor. Plug-in vehicles can load their batteries using electricity from the grid. Fuel-cell cars use hydrogen to generate electricity. It has been shown that heavy metals in battery manufacturing and other aspects of the battery lifecycle increase the environmental impact of this type of cars (Tagliaferri et al., 2016).

In this study, conventional vehicles on the island are substituted by electric and fuel-cell vehicles (Koroneos and Tsarouhis, 2012).

In past work, several scenarios for stand-alone renewable-based energy conversion systems were proposed for covering the electricity needs of the island. It is assumed that electricity-based space cooling, water heating systems and electric cars studied here will be supplied by the proposed stand-alone renewable power stations. In addition, the hydrogen used in the fuel-cell cars is also assumed to be a byproduct of the renewable power stations. 


\section{THERMAL ENERGY}

The housing sector is a promising area for implementing energy improvement measures on Skyros, since approximately $64 \%$ of the buildings on the island were built before 1980 , i.e., before the law on thermal regulation had been introduced in the country. Public buildings housing hospitals, schools, military and public/municipal services also offer a relatively good potential for energy reduction on Skyros. Hotels, on the other hand, have a lower overall potential for improvement mainly due to the limited infrastructure available on the island. The analysis presented here includes all of the different property types of the island.

It should be mentioned that the performance of a thermal system depends strongly on the condition of each property type. Based on the year of construction and used materials, a building can be classified into a different class of energy effectiveness. An important way to minimize heat losses or gains in buildings is adequate thermal insulation, represented by the overall heat transfer coefficient of materials (U-values). This factor has been improving in all European countries, especially in the last decades (Baker, 2011; Buildings Performance Institute Europe, 2011). However, the insulation of buildings has been improving throughout the years not only because of the improvement of building materials, but also due to the introduction of new laws. According to the registry of buildings in 2000 (Hellenic Statistical Authority -ELSTAT, 2008), 35.1\% of the buildings on Skyros were built with concrete $34.9 \%$ with bricks/concrete blocks and $27.6 \%$ with stone. In this analysis, all buildings are assumed to perform in a similar manner. In addition, it is assumed that the proposed renewable system achieves total coverage of the space-heating thermal energy requirement.

\section{Technology Proposal and Evaluation}

Skyros is shown to have a medium potential priority for woodfuel exploitation (Caralis and Emmanouilidis, 2009), which implies that the installation of new efficient and relatively economic woodstoves could be considered. However, although biomass may be considered a carbon-neutral fuel, its net emissions depend strongly on the applied processing procedure preceding its use. For the purpose of the analysis presented here, it was decided to propose and evaluate a system that does not generate greenhouse gas emissions during its use.

The main parts of the proposed system are shown in Figure 1. Those are vacuum-tube solar collectors $(\Sigma 1)$, a solar heat exchanger $(\Sigma 2)$, the recirculation of the water return $(\Sigma 4)$, a geothermal heat exchanger $(\Sigma 5)$, used only for water pre-heating purposes, and a radiant floor system ( $\Sigma 3)$ (Koroneos and Tsarouhis, 2012). The evaluated tube collectors are expensive relative to other alternatives but they are efficient, durable and have a longer lifetime. The sizing of the solar-thermal system depends on the surface area of the space that needs to be heated. For example, the mean surface area of residences $\left(66.4 \mathrm{~m}^{2}\right)$ is covered with solar collectors of a total surface area of 34 $\mathrm{m}^{2}$, i.e., 9 units of 30-tube solar collectors (of $3.7 \mathrm{~m}^{2} \mathrm{each}$ ), and a hot water storage tank with a capacity of 1,300 1. The temperature of the hot water in the reservoir is $59^{\circ} \mathrm{C}$ and $42{ }^{\circ} \mathrm{C}$ in the floor system.

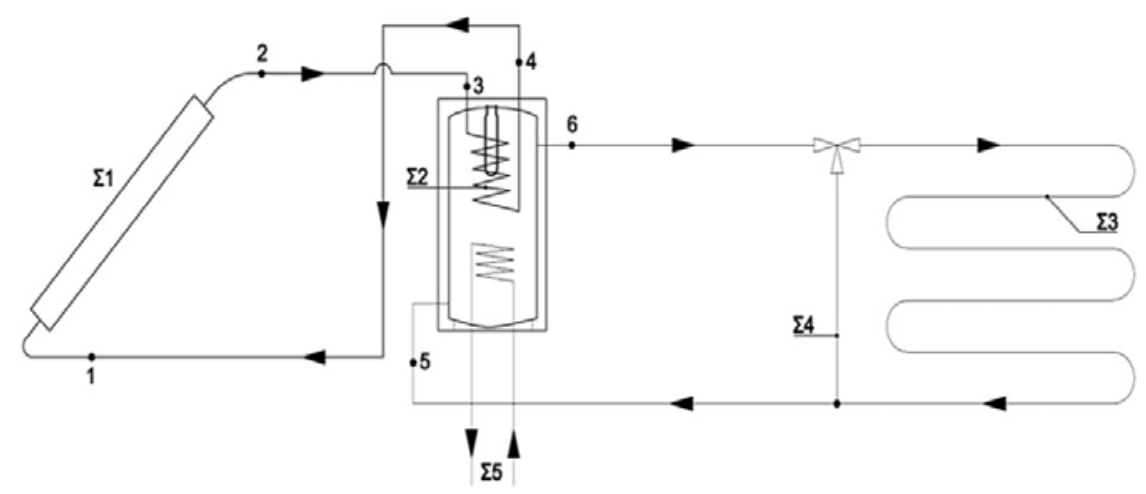

Figure 1. The analyzed solar-thermal system (Koroneos and Tsarouhis, 2012)

The annual thermal energy required, the associated costs and $\mathrm{CO}_{2}$ emissions on Skyros can be seen in Table 2. The energy consumed in each settlement of the island is presented in Table 3. Based on the energy needs and the quantity of each property type, the total number of solar-thermal systems required are estimated and shown in Table 4.

To number of solar-thermal systems required for implementation in residences are calculated accounting for only buildings with central heating. Table 4 shows the estimated number of residences with central heating calculated as a constant $30 \%$ of the total residences in each settlement of the island. The remaining information of the table on the number of businesses, schools etc. are extracted from statistical information about the island published by ELSTAT. 
Table 2. Thermal energy requirements on Skyros, associated costs and $\mathrm{CO}_{2}$ emissions

\begin{tabular}{|c|c|c|c|c|c|c|c|c|c|}
\hline & Residences & Schools & Hospital & Airport & $\begin{array}{c}\text { Military } \\
\text { bases }\end{array}$ & $\begin{array}{c}\text { Offices/ } \\
\text { shops }\end{array}$ & $\begin{array}{c}\text { Restaurants/ } \\
\text { bars }\end{array}$ & $\begin{array}{c}\text { Touristic } \\
\text { accommodations }\end{array}$ & Total \\
\hline $\begin{array}{l}\text { Space heating } \\
{[\mathrm{MWh} / \mathrm{a}]}\end{array}$ & 6,804 & 167 & 159 & 79 & 1,116 & 2,041 & 323 & 156 & 10,846 \\
\hline Diesel oil needed [t/a] & 572 & 14 & 13 & 7 & 94 & 172 & 27 & 13 & 912 \\
\hline Cost of fuel [€/a] & 689,835 & 16,952 & 16,167 & 8,003 & 113,172 & 206,942 & 32,726 & 15,862 & $1,099,659$ \\
\hline $\mathrm{CO}_{2}$ emissions $[\mathrm{t} / \mathrm{a}]$ & 1,814 & 45 & 43 & 21 & 298 & 544 & 86 & 42 & 2,892 \\
\hline $\begin{array}{l}\text { Water heating } \\
{[\mathrm{MWh} / \mathrm{a}]}\end{array}$ & 1,670 & 0 & 0 & 0 & 0 & 0 & 0 & 142 & 1,812 \\
\hline Diesel oil needed $[\mathrm{t} / \mathrm{a}]$ & 140 & 0 & 0 & 0 & 0 & 0 & 0 & 12 & 152 \\
\hline Cost of fuel $[€ / \mathrm{a}]$ & 169,292 & 0 & 0 & 0 & 0 & 0 & 0 & 14,368 & 183,661 \\
\hline $\mathrm{CO}_{2}$ emissions [t/a] & 445 & 0 & 0 & 0 & 0 & 0 & 0 & 38 & 483 \\
\hline
\end{tabular}

Table 3. Thermal energy consumption for space heating in each settlement

\begin{tabular}{|c|c|c|c|c|c|c|c|c|c|}
\hline & $\begin{array}{c}\text { Residences } \\
\text { [MWh] }\end{array}$ & $\begin{array}{l}\text { Schools } \\
\text { [MWh] }\end{array}$ & $\begin{array}{c}\text { Hospital } \\
\text { [MWh] }\end{array}$ & $\begin{array}{l}\text { Airport } \\
\text { [MWh] }\end{array}$ & $\begin{array}{c}\text { Military } \\
\text { bases } \\
{[\mathrm{MWh}]}\end{array}$ & $\begin{array}{c}\text { Offices / } \\
\text { shops } \\
\text { [MWh] }\end{array}$ & $\begin{array}{c}\text { Restaurants/ } \\
\text { bars } \\
{[\mathrm{MWh}]} \\
\end{array}$ & $\begin{array}{c}\text { Tourist } \\
\text { accommodations } \\
{[\mathrm{MWh}]} \\
\end{array}$ & $\begin{array}{l}\text { Total } \\
\text { [MWh] }\end{array}$ \\
\hline Aspous & 243 & 0 & 0 & 0 & 0 & 73 & 12 & 27 & 354 \\
\hline$\frac{1}{\text { Atsitsa }}$ & 30 & 0 & 0 & 0 & 0 & 9 & 1 & 2 & 42 \\
\hline Acherounes & 148 & 0 & 0 & 0 & 0 & 44 & 7 & 9 & 208 \\
\hline Achilli & 120 & 0 & 0 & 0 & 0 & 36 & 6 & 0 & 162 \\
\hline$\overline{\text { Kalamitsa }}$ & 98 & 0 & 0 & 0 & 0 & 29 & 5 & 11 & 143 \\
\hline Kalikri & 98 & 0 & 0 & 0 & 0 & 29 & 5 & 0 & 132 \\
\hline Kira Panagia & 0 & 0 & 0 & 0 & 0 & 0 & 0 & 0 & 0 \\
\hline Linaria & 264 & 0 & 0 & 0 & 0 & 79 & 13 & 4 & 360 \\
\hline Loutro & 64 & 0 & 0 & 0 & 0 & 19 & 3 & 2 & 88 \\
\hline Molos & 1,404 & 12 & 0 & 0 & 0 & 421 & 67 & 87 & 1,992 \\
\hline Nifi & 70 & 0 & 0 & 0 & 0 & 21 & 3 & 0 & 95 \\
\hline Pefkos & 55 & 0 & 0 & 0 & 0 & 16 & 3 & 0 & 73 \\
\hline Sarakinon (islet) & 0 & 0 & 0 & 0 & 0 & 0 & 0 & 0 & 0 \\
\hline Skyropoula (islet) & 0 & 0 & 0 & 0 & 0 & 0 & 0 & 0 & 0 \\
\hline Skyros & 3,766 & 155 & 159 & 0 & 0 & 1,130 & 179 & 13 & 5,402 \\
\hline Trachi & 445 & 0 & 0 & 79 & 957 & 134 & 21 & 0 & 1,636 \\
\hline Tristomo & 0 & & 0 & 0 & 159 & 0 & 0 & 0 & 159 \\
\hline Total & 6,804 & 167 & 159 & 79 & 1,116 & 2,041 & 323 & 156 & 10,846 \\
\hline
\end{tabular}

Table 4. Number of solar-thermal systems in each settlement

\begin{tabular}{|c|c|c|c|c|c|c|c|c|}
\hline & Residences & Schools & Hospital & Airport & $\begin{array}{c}\text { Military } \\
\text { bases }\end{array}$ & $\begin{array}{c}\text { Offices/ } \\
\text { shops }\end{array}$ & $\begin{array}{c}\text { Restaurants/ } \\
\text { bars }\end{array}$ & $\begin{array}{c}\text { Tourist } \\
\text { accommodations }\end{array}$ \\
\hline Aspous & 35 & 0 & 0 & 0 & 0 & 3 & 9 & 12 \\
\hline Atsitsa & 4 & 0 & 0 & 0 & 0 & 0 & 1 & 1 \\
\hline Acherounes & 22 & 0 & 0 & 0 & 0 & 2 & 5 & 4 \\
\hline Achilli & 18 & 0 & 0 & 0 & 0 & 1 & 4 & 0 \\
\hline Kalamitsa & 14 & 0 & 0 & 0 & 0 & 1 & 4 & 5 \\
\hline Kalikri & 14 & 0 & 0 & 0 & 0 & 1 & 4 & 0 \\
\hline Kira Panagia & 0 & 0 & 0 & 0 & 0 & 0 & 0 & 0 \\
\hline Linaria & 38 & 0 & 0 & 0 & 0 & 3 & 10 & 2 \\
\hline Loutro & 9 & 0 & 0 & 0 & 0 & 1 & 2 & 1 \\
\hline Molos & 205 & 1 & 0 & 0 & 0 & 15 & 52 & 39 \\
\hline Nifi & 10 & 0 & 0 & 0 & 0 & 1 & 3 & 0 \\
\hline Pefkos & 8 & 0 & 0 & 0 & 0 & 1 & 2 & 0 \\
\hline Sarakinon (islet) & 0 & 0 & 0 & 0 & 0 & 0 & 0 & 0 \\
\hline Skyropoula (islet) & 0 & 0 & 0 & 0 & 0 & 0 & 0 & 0 \\
\hline Skyros & 550 & 3 & 1 & 0 & 0 & 40 & 139 & 6 \\
\hline Trachi & 65 & 0 & 0 & 1 & 1 & 5 & 16 & 0 \\
\hline Tristomo & 0 & 0 & 0 & 0 & 1 & 0 & 0 & 0 \\
\hline Total & 993 & 4 & 1 & 1 & 2 & 73 & 252 & 70 \\
\hline
\end{tabular}

\section{Economic Considerations}

It is assumed that the economic life of the solar-thermal systems is 20 years and that each 30-tube unit of solar collectors with storage tanks and the associated accompanying components (heat exchangers, etc.) costs 2,000 €. In addition, it is assumed that the radiant floor costs $54 € / \mathrm{m}^{2}$ and it covers $40 \%$ of the surface area of residences and $80 \%$ of the surface area of hospital, schools, offices and shops, the airport, and the military bases. The cost of operating and maintenance of the units is considered to be negligible compared to their investment costs. With the above assumptions, the investment costs of the solar-thermal systems for each settlement are presented in Table 5. 
European Journal of Sustainable Development Research, 2(1), 05

Table 5. Potential costs of solar-thermal systems in each settlement

\begin{tabular}{|c|c|c|c|c|c|c|c|c|c|}
\hline & $\begin{array}{c}\text { Residences } \\
{[€]}\end{array}$ & $\begin{array}{c}\text { Schools } \\
{[€]}\end{array}$ & $\begin{array}{c}\text { Hospital } \\
{[€]}\end{array}$ & $\begin{array}{l}\text { Airport } \\
{[€]}\end{array}$ & $\begin{array}{c}\text { Military } \\
\text { bases } \\
{[€]}\end{array}$ & $\begin{array}{c}\text { Offices/ } \\
\text { shops } \\
{[€]}\end{array}$ & $\begin{array}{c}\text { Restaurants / } \\
\text { bars } \\
{[€]}\end{array}$ & $\begin{array}{c}\text { Tourist } \\
\text { accommo } \\
\text { dations } \\
{[€]}\end{array}$ & \\
\hline Aspous & 20,175 & 0 & 0 & 0 & 0 & 85,137 & 43,341 & 263,032 & \\
\hline Atsitsa & 86,979 & 0 & 0 & 0 & 0 & 26,997 & 47,383 & 21,919 & \\
\hline Acherounes & 434,896 & 0 & 0 & 0 & 0 & 134,983 & 236,917 & 87,677 & \\
\hline Achilli & 354,608 & 0 & 0 & 0 & 0 & 110,063 & 193,178 & 0 & \\
\hline Kalamitsa & 287,700 & 0 & 0 & 0 & 0 & 89,296 & 156,730 & 109,597 & \\
\hline Kalikri & 287,700 & 0 & 0 & 0 & 0 & 89,296 & 156,730 & 0 & \\
\hline Kira Panagia & 0 & 0 & 0 & 0 & 0 & 0 & 0 & 0 & \\
\hline Linaria & 776,122 & 0 & 0 & 0 & 0 & 240,893 & 422,805 & 43,839 & \\
\hline Loutro & 187,340 & 0 & 0 & 0 & 0 & 58,147 & 102,056 & 21,919 & \\
\hline Molos & $4,134,857$ & 86,284 & 0 & 0 & 0 & $1,283,377$ & $2,252,532$ & 854,853 & \\
\hline Nifi & 207,412 & 0 & 0 & 0 & 0 & 64,376 & 112,991 & 0 & \\
\hline Pefkos & 160,577 & 0 & 0 & 0 & 0 & 49,840 & 87,477 & 0 & \\
\hline Sarakinon (islet) & 0 & 0 & 0 & 0 & 0 & 0 & 0 & 0 & \\
\hline Skyropoula (islet) & 0 & 0 & 0 & 0 & 0 & 0 & 0 & 0 & \\
\hline Skyros & $11,086,503$ & 446,647 & $1,674,726$ & 0 & 0 & $3,441,027$ & $6,039,555$ & 131,516 & \\
\hline Trachi & $1,311,379$ & 0 & 0 & 392,275 & $2,180,579$ & 407,026 & 714,395 & 0 & \\
\hline Tristomo & 0 & 0 & 0 & 0 & 363,430 & 0 & 0 & 0 & \\
\hline Total & $19,336,248$ & 532,931 & $1,674,726$ & 392,275 & $2,544,009$ & $6,080,457$ & $10,566,090$ & $1,534,352$ & $42,661,088$ \\
\hline
\end{tabular}

Table 6. Cost of diesel oil for a 20-year period and investment costs of solar-thermal systems

\begin{tabular}{|c|c|c|c|c|c|c|c|c|c|}
\hline & Residences & Schools & Hospital & Airport & $\begin{array}{l}\text { Military } \\
\text { bases }\end{array}$ & $\begin{array}{c}\text { Offices/ } \\
\text { shops }\end{array}$ & $\begin{array}{c}\text { Restaurants / } \\
\text { bars }\end{array}$ & $\begin{array}{c}\text { Tourist } \\
\text { accommodations }\end{array}$ & Total \\
\hline & {$[€]$} & {$[€]$} & {$[€]$} & {$[€]$} & {$[€]$} & {$[€]$} & {$[€]$} & {$[€]$} & \\
\hline Cost of fuel & $13,796,696$ & 339,031 & 323,350 & 160,053 & $2,263,449$ & $4,138,846$ & 654,520 & 317,234 & $21,993,178$ \\
\hline \multicolumn{10}{|l|}{ Solar-thermal } \\
\hline No subsidies & $19,336,248$ & 532,931 & $1,674,726$ & 392,275 & $2,544,009$ & $6,080,457$ & $10,566,090$ & $1,534,352$ & $42,661,088$ \\
\hline $30 \%$ subsidy & $13,535,373$ & 373,052 & $1,172,308$ & 274,593 & $1,780,806$ & $4,256,320$ & $7,396,263$ & $1,074,046$ & $29,862,761$ \\
\hline $50 \%$ subsidy & $9,668,124$ & 266,466 & 837,363 & 196,138 & $1,272,004$ & $3,040,229$ & $5,283,045$ & 767,176 & $21,330,544$ \\
\hline $70 \%$ subsidy & $5,800,874$ & 159,879 & 502,418 & 117,683 & 763,203 & $1,824,137$ & $3,169,827$ & 460,306 & $12,798,326$ \\
\hline
\end{tabular}

The cost of solar thermal systems is calculated based on the total square meters of the different types of property units and their specific energy consumption $\left(\mathrm{MWh} / \mathrm{m}^{2}\right)$ relative to residential units. The investment costs of the solar thermal systems are relatively high mainly due to the expensive solar collectors that must be installed. Nevertheless, it should be considered that environmentally friendly measures can be subsidized at a significant percentage by public funds.

Solar-thermal units on properties with a seasonal character (e.g., restaurants/bars and tourist accommodations) or variable operation (e.g., hospital) must be oversized to cover the highest energy needs of each space. In these cases, diesel oil can be used in a more effective manner since it can be consumed only when needed. Table 6 presents the comparison of the diesel costs and the investment costs of the proposed solar-thermal systems with three subsidy scenarios.

As seen, the investment cost of the solar-thermal systems becomes smaller than the cost of diesel used for space heating purposes with subsidy scenarios equal or higher than $50 \%$.

\section{Environmental Considerations}

Since the use of the solar-thermal system is assumed to have zero emissions, the environmental evaluation considers only its production stage. The total weighted impact per $\mathrm{kWh}$ generated in the reference system presented in Ref. (Koroneos and Tsarouhis, 2012) is linked to $0.479 \mathrm{~g}$ of pollutants. The greenhouse gas emissions of the system are found to be $0.016 \mathrm{~g} / \mathrm{kWh}$. In the analysis presented here, the greenhouse gas emissions have been adjusted to the size of the solar thermal systems installed on each property type.

The total annual greenhouse gases of the systems to be installed in each settlement of the island are presented in Table 7. It is seen that the total greenhouse gases generated by the production of the solar-thermal systems do not exceed the $0.5 \mathrm{t} / \mathrm{a}$. When looking at the $\mathrm{CO}_{2}$ emissions (part of the greenhouse gas emissions) of the combustion of diesel currently used for space heating purposes, it is found that they account for somewhat less than $3 \mathrm{t} / \mathrm{a}$. This significant difference shows that greenhouse gas emissions from the production phase of the renewable system are insignificant compared to those of the use phase (combustion) of the diesel oil. 
Table 7. Greenhouse gases from the production stage of the solar-thermal systems in each settlement [kg/a]

\begin{tabular}{lccccccccc}
\hline & $\begin{array}{c}\text { Residenc } \\
\text { es }\end{array}$ & Schools & Hospital & Airport & $\begin{array}{c}\text { Military } \\
\text { bases }\end{array}$ & $\begin{array}{c}\text { Offices/ } \\
\text { shops }\end{array}$ & $\begin{array}{c}\text { Restaurants/ } \\
\text { bars }\end{array}$ & $\begin{array}{c}\text { Tourist } \\
\text { accommodations }\end{array}$ & Total \\
\hline Aspous & 1.72 & 0.00 & 0.00 & 0.00 & 0.00 & 0.62 & 0.10 & 0.70 & $\mathbf{3 . 1 5}$ \\
\hline Atsitsa & 0.21 & 0.00 & 0.00 & 0.00 & 0.00 & 0.08 & 0.01 & 0.06 \\
\hline Acherounes & 1.05 & 0.00 & 0.00 & 0.00 & 0.00 & 0.38 & 0.06 & 0.23 & $\mathbf{0 . 3 6}$ \\
\hline Achilli & 0.85 & 0.00 & 0.00 & 0.00 & 0.00 & 0.31 & 0.05 & 0.00 & $\mathbf{1 . 2 1}$ \\
\hline Kalamitsa & 0.69 & 0.00 & 0.00 & 0.00 & 0.00 & 0.25 & 0.04 & 0.29 & $\mathbf{1 . 2 8}$ \\
\hline Kalikri & 0.69 & 0.00 & 0.00 & 0.00 & 0.00 & 0.25 & 0.04 & 0.00 & $\mathbf{0 . 9 8}$ \\
\hline Kira Panagia & 0.00 & 0.00 & 0.00 & 0.00 & 0.00 & 0.00 & 0.00 & 0.00 & $\mathbf{0 . 0 0}$ \\
\hline Linaria & 1.87 & 0.00 & 0.00 & 0.00 & 0.00 & 0.67 & 0.11 & 0.12 & $\mathbf{2 . 7 7}$ \\
\hline Loutro & 0.45 & 0.00 & 0.00 & 0.00 & 0.00 & 0.16 & 0.03 & 0.06 & $\mathbf{0 . 7 0}$ \\
\hline Molos & 9.95 & 1.78 & 0.00 & 0.00 & 0.00 & 3.60 & 0.57 & 2.29 & $\mathbf{1 8 . 1 8}$ \\
\hline Nifi & 0.50 & 0.00 & 0.00 & 0.00 & 0.00 & 0.18 & 0.03 & 0.00 & $\mathbf{0 . 7 1}$ \\
\hline Pefkos & 0.39 & 0.00 & 0.00 & 0.00 & 0.00 & 0.14 & 0.02 & 0.00 & $\mathbf{0 . 5 5}$ \\
\hline Sarakinon (islet) & 0.00 & 0.00 & 0.00 & 0.00 & 0.00 & 0.00 & 0.00 & 0.00 & $\mathbf{0 . 0 0}$ \\
\hline Skyropoula (islet) & 0.00 & 0.00 & 0.00 & 0.00 & 0.00 & 0.00 & 0.00 & 0.00 & $\mathbf{0 . 0 0}$ \\
\hline Skyros & 26.67 & 23.19 & 8.50 & 0.00 & 0.00 & 9.64 & 1.52 & 0.35 & $\mathbf{6 9 . 8 8}$ \\
\hline Trachi & 3.15 & 0.00 & 0.00 & 8.42 & 357.21 & 1.14 & 0.18 & 0.00 & $\mathbf{3 7 0 . 1 0}$ \\
\hline Tristomo & 0.00 & 0.00 & 0.00 & 0.00 & 5.01 & 0.00 & 0.00 & 0.00 & $\mathbf{5 . 0 1}$ \\
\hline Total & $\mathbf{4 8 . 1 9}$ & $\mathbf{2 4 . 9 7}$ & $\mathbf{8 . 5 0}$ & $\mathbf{8 . 4 2}$ & $\mathbf{3 6 2 . 2 1}$ & $\mathbf{1 7 . 4 2}$ & $\mathbf{2 . 7 5}$ & $\mathbf{4 . 1 1}$ & $\mathbf{4 7 6 . 5 7}$ \\
\hline & & & & & & & &
\end{tabular}

\section{TRANSPORT SECTOR}

The municipality of Skyros possesses certain vehicles that serve the needs of its departments as presented in Table 8 (Municipality of Skyros, 2014). To estimate the number of vehicles on the island, we used general country statistics. Population and car ownership statistics in Greece by the Hellenic Statistical Authority show that approximately one in four people (26\%) living in the prefecture of Evvoia, that Skyros is part of, own a private car (Hellenic Statistical Authority -ELSTAT, 2009). This percentage increases on islands, reaching, in some cases, the high percentage of $44 \%$. This depends, however, on the size of the population, the age of the people and their everyday activities. For Skyros a mean value of 34\% can be assumed (one in three people own a private car) due to the relatively high percentage of the island's population in young and middle-aged people. Approximately one in six people (16\% of the population) can be assumed to own a private truck for farming and/or other purposes.

Table 8. Vehicles of the municipality of Skyros

\begin{tabular}{|c|c|c|c|c|}
\hline & Department/service & Type of vehicle & Type of fuel & $\begin{array}{l}\text { Fuel consumption } \\
\text { threshold }[1 / \text { month }]\end{array}$ \\
\hline 1. & \multirow{4}{*}{ Finance Directors } & Bus FIAT & Diesel & 254 \\
\hline 2. & & $4 \times 4$ SUZUKI & Unleaded fuel & 135 \\
\hline 3. & & Motorcycle KAWASAKI & Unleaded fuel & 26 \\
\hline 4. & & Passenger car HYUNDAI & Unleaded fuel & 112 \\
\hline 1. & \multirow{8}{*}{ Cleaning \& Electrolighting } & Garbage truck MERCEDES & Diesel & 1060 \\
\hline 2. & & Garbage truck MERCEDES & Diesel & 592 \\
\hline 3. & & Garbage truck VOLVO & Diesel & 516 \\
\hline 4. & & Garbage truck NISSAN & Diesel & 625 \\
\hline 5. & & Truck MERCEDES & Diesel & 275 \\
\hline 6. & & Truck MERCEDES & Diesel & 197 \\
\hline 7. & & Truck RENAULT & Diesel & 267 \\
\hline 8. & & Truck with aerial platform FIAT & Diesel & No limit \\
\hline 9. & \multirow{4}{*}{ Water Supply Sewerage } & Van MAZDA & Unleaded fuel & 165 \\
\hline 10. & & Van OPEL & Unleaded fuel & 107 \\
\hline 11. & & Van OPEL & Unleaded fuel & 155 \\
\hline 12. & & Tanker MERCEDES & Diesel & 495 \\
\hline 13. & & Excavator - Backhoe KOMATSU & Diesel & No limit \\
\hline 14. & & Grader GREINTER & Diesel & No limit \\
\hline 15. & & Crawler loader CATERPILLAR & Diesel & No limit \\
\hline
\end{tabular}

\section{Technology Proposal and Evaluation}

The zero-emission solution this report studies for the transport sector is the replacement of the vehicle fleet of Skyros with electric and hydrogen-fueled vehicles. Although such an action is challenging and cannot happen instantaneously, it is worthy of evaluation and investigation for two primary reasons: electricity for hydrogen generation and for utilization in electric cars can offer (1) a way to stabilize and ensure reliable and more secure 
Table 9. Fuel requirement of fuel-cell and electric vehicles

\begin{tabular}{|c|c|c|c|c|}
\hline & Private cars & Private trucks & Public vehicles & Total \\
\hline Number of vehicles & 1,027 & 475 & 15 & 1,042 \\
\hline Total use $[\mathrm{km} / \mathrm{a}]$ & $1,439,200$ & $1,028,000$ & 5,097 & $1,444,297$ \\
\hline Electric vehicles & 719 & 332 & 11 & 730 \\
\hline Use $[\mathrm{km} / \mathrm{a}]$ & $1,007,440$ & 719,600 & 3,568 & $1,011,008$ \\
\hline Fuel use $[\mathrm{kWh} / \mathrm{a}]$ & 147,086 & 105,062 & 521 & 147,607 \\
\hline Fuel cell vehicles & 308 & 143 & 4 & 312 \\
\hline Use $[\mathrm{km} / \mathrm{a}]$ & 431,760 & 308,400 & 1,529 & 433,289 \\
\hline Fuel use [tonnes $\mathrm{H}_{2} / \mathrm{a}$ ] & 13.67 & 9.77 & 0.05 & 14 \\
\hline Electricity required $[\mathrm{GJ} / \mathrm{a}]$ & & 592,198 & 53 & 592,251 \\
\hline Hydrogen required [GJ/a] & & 245,496 & 36 & 245,532 \\
\hline
\end{tabular}

operation of renewable power stations by using electricity surpluses and (2) an opportunity to use fuels generated from renewable resources that, in contrast to biofuels, do not have direct greenhouse gas emissions.

In the following economic and environmental investigation, it is assumed that $70 \%$ of the existing vehicles on Skyros will be replaced with electric cars and 30\% with fuel-cell cars. The electric car used as reference is the Nissan Leaf that operates on a $24 \mathrm{kWh}$ lithium-ion battery (Nissan, 2016). The hydrogen reference car is the Hyundai ix35 with a reservoir capacity of $5.63 \mathrm{~kg}$ of $\mathrm{H}_{2}$ (Hyundai Motor Company, 2015). The estimated current vehicles and the proposed fleet are shown in Table 9.

Stand-alone renewable power plants evaluated for the case of Skyros were found to generate surpluses of electricity of 6,721 and 2,832 MWh, respectively (Petrakopoulou, Robinson and Loizidou, 2016a, 2016b). With the proposed electrolyzer unit of the plants, $379.4 \mathrm{MWh} / \mathrm{a}$ are needed to generate the hydrogen required to fuel the fuel-cell cars. In addition, another 148.0 MWh/a are needed to power the electric cars. The remaining electricity surplus of the plants can be used to generate hydrogen to sell in a potentially mature hydrogen market at the time of the materialization of this proposal. The annual gain through the sale of the generated hydrogen can be used to subsidize the renewable development of the island.

\section{Economic Considerations}

A transport sector fully reliant on hydrogen and electric vehicles calls for the complete replacement of the current vehicle fleet of the island and assumes that all technological and operational limitations of the two technologies have already been managed. Furthermore, the purchase and maintenance costs of the new vehicles, involving, for example, the replacement of the car battery, would result in an overall substantial economic expenditure. However, it would provide the opportunity to the inhabitants of Skyros to use efficient, zero-emission cars based on locally-produced fuels.

The fuel costs calculated for the existing public passenger cars of the island can be seen in Table 10. Detailed calculations of the fuel consumption can be found in Ref. (Petrakopoulou, 2015a). The specific fuel consumption presented here refers to existing vehicles, the age of which may vary significantly, and is thus not representative of the consumption reported for newer cars with better efficiencies. The hydrogen price used is $5 € / \mathrm{kg}$. With this price, a newly-built hydrogen station would recoup the costs of the station through the sales of hydrogen within approximately 20 years (Melaina and Penev, 2013). The cost of electricity used in the electric cars is assumed to be that reported for the country in $2014(0.130 € / \mathrm{kWh})$ (Eurostat, 2015). The life cycle of the new vehicles is 10 years.

Table 10. Consumption and purchase price of different types of passenger cars

\begin{tabular}{|c|c|c|c|c|c|}
\hline Type of car & $\begin{array}{c}\text { Curb weight } \\
{[\mathrm{kg}]}\end{array}$ & $\begin{array}{c}\text { Purchase price } \\
{[€]}\end{array}$ & $\begin{array}{c}\text { Fuel consumption } \\
{[\mathrm{MJ} / 100 \mathrm{~km}]}\end{array}$ & $\begin{array}{l}\text { Fuel price } \\
{[€ / 100 \mathrm{~km}]}\end{array}$ & $\begin{array}{c}\text { Distance } \\
{[\mathrm{km}]}\end{array}$ \\
\hline \multicolumn{6}{|l|}{ Current situation* } \\
\hline Gasoline & - & - & 397.64 & 14.91 & - \\
\hline Diesel & - & - & 251.88 & 7.88 & - \\
\hline Electric & 1,493 & 29,010 & 59.83 & 2.31 & 135 \\
\hline Fuel cell car & 1,850 & 73,385 & 134.90 & 4.75 & 593 \\
\hline
\end{tabular}

*Refers to private passenger cars. The age of the cars varies.

The main expenditure associated with the proposed cars is their purchase cost (Table 11). Although the cost of vehicles will differ depending on their type, use and size, for simplicity a $20 \%$ increase for trucks and $50 \%$ increase of public vehicles (mainly big trucks) is applied. In the case of the electric vehicles, the cost of the battery of the car also poses an important cost. The battery of the electric cars is assumed to be changed twice in the lifetime of the car (assumed 10 years). 
Table 11. Total cost of the new vehicle fleet on Skyros

\begin{tabular}{|c|c|c|c|c|}
\hline & Private cars & Private trucks & Public vehicles & Total \\
\hline \multicolumn{5}{|l|}{ Electric vehicles } \\
\hline Purchase cost $[€]$ & $20,858,190$ & $11,557,584$ & 478,665 & $21,336,855$ \\
\hline Cost of battery $[€ / a]$ & 93,470 & 431,600 & 14,300 & 107,770 \\
\hline Fuel cost $[€ / \mathrm{a}]$ & 23,283 & 16,631 & 82 & 23,366 \\
\hline \multicolumn{5}{|l|}{ Fuel cell vehicles } \\
\hline Purchase cost $[€]$ & $22,602,552$ & $12,592,851$ & 440,309 & $23,042,862$ \\
\hline Cost of PEMFC* $[€ / \mathrm{a}]$ & 5,063 & 2,351 & 66 & 5,129 \\
\hline Fuel cost $[€ / \mathrm{a}]$ & 20,509 & 14,649 & 73 & 20,581 \\
\hline
\end{tabular}

As seen in Table 12, the total cost of fuel used currently in the transport sector is $319,000 € /$ a (Petrakopoulou, 2015a). The combined fuel cost of fuel-cell and electric vehicles, on the other hand, is calculated to be $43,947 € / a$ (Table 11), i.e., more than seven times less than that of the current situation based on conventional fuels. The maintenance costs of the new vehicle fleet, however, is found to be approximately 3.6 times higher. Overall, the combination of fuel and maintenance costs of the fuel-cell and electric vehicles is found to be $45 \%$ that of the current fleet.

Table 12. Total costs of existing and proposed cars

\begin{tabular}{lcc}
\hline & Existing cars & Fuel cell and electric cars \\
\hline Purchase cost $[€]$ & - & $44,379,717$ \\
\hline Maintenance cost (battery) $[€ /$ a] & $31,260^{*}$ & 112,899 \\
\hline Fuel cost $[€ /$ a $]$ & 319,000 & 43,947
\end{tabular}

* Assumed price of a typical car battery: $150 €$, lifetime: 5 years, replacements: 2 within the 10 years.

\section{Environmental considerations}

Gasoline and diesel vehicles, currently used on the island generate the $\mathrm{CO}_{2}$ emissions shown in Table 13. Zero emissions from the transport sector utilizing hydrogen- and electric-based vehicles means the direct reduction of the $\mathrm{CO}_{2}$ emissions of Skyros by 673 tones annually. This quantity is equal to the annual $\mathrm{CO}_{2}$ emissions of a $320-$ $\mathrm{kW}$ natural gas plant with an annual capacity factor (percentage of hours of full load operation in a year) of $70 \%$.

Table 13. Annual avoided $\mathrm{CO}_{2}$ emissions in the transport sector on Skyros

\begin{tabular}{lccc}
\hline & \multicolumn{3}{c}{$\mathbf{C O}_{2}$ emissions [t/a] } \\
\cline { 2 - 4 } Diesel & Public vehicles & Private vehicles & Total \\
\hline Gasoline & 161 & 147 & 308 \\
\hline
\end{tabular}

It is assumed that the electricity used in the electric cars and the hydrogen used in the fuel-cell cars are provided by a renewable plant that does not produce harmful emissions. Since the operation of the cars does not generate any emissions either, the use of both the electric and hydrogen cars are considered to generate zero air pollutants and have zero direct greenhouse gas emissions. However, there are emissions generated during the production phase of the cars. The calculated total emissions are shown in Table 14. For the purpose of these calculations, it was assumed that trucks have $20 \%$ higher air pollutants and greenhouse gas emissions. This percentage was raised to $50 \%$ for public vehicles. The intermediate calculations for passenger vehicles only are shown in Table 15, while the exact methodology followed is explained in detail in Ref. (Pistoia et al., 2010).

Table 14. Specific emissions of the curb of a typical vehicle $[\mathrm{kg} / \mathrm{kg}]$

\begin{tabular}{lllc}
\hline & $\mathbf{C O}$ & $\mathbf{N O}_{\mathbf{X}}$ & GHG \\
\hline Extraction & $1.20 \mathrm{E}-02$ & $5.06 \mathrm{E}-03$ & $1.93 \mathrm{E}+00$ \\
\hline Manufacturing & $1.88 \mathrm{E}-04$ & $2.40 \mathrm{E}-03$ & $1.23 \mathrm{E}+00$ \\
\hline End of life & $1.77 \mathrm{E}-06$ & $3.58 \mathrm{E}-05$ & $1.40 \mathrm{E}-02$ \\
\hline Total & $\mathbf{1 . 2 2 E - 0 2}$ & $\mathbf{7 . 5 0 E}-\mathbf{0 3}$ & $\mathbf{3 . 1 7 E}+\mathbf{0 0}$ \\
\hline
\end{tabular}

It can be seen that the avoided emissions during the use phase of the new fleet will need approximately six years to balance out the emissions of the manufacturing of the electric- and hydrogen-based cars. 
Table 15. Intermediate calculation results for passenger vehicles

\begin{tabular}{lcccccccc}
\hline & $\begin{array}{l}\text { Curb weight } \\
{[\mathrm{kg}]}\end{array}$ & $\begin{array}{c}\text { Battery weight } \\
{[\mathrm{kg}]}\end{array}$ & $\begin{array}{c}\text { Net weight } \\
{[\mathrm{kg}]}\end{array}$ & $\begin{array}{c}\text { Air pollutants battery } \\
{[\mathrm{kg}]}\end{array}$ & $\begin{array}{c}\text { GHG* } \\
{[\mathrm{kg}]}\end{array}$ & Air pollutants & GHG car \\
\hline Electric cars & 1,493 & 377 & 1,116 & 5.40 & 952.64 & 5.40 & {$[\mathrm{~kg}]$} \\
\hline Fuel cell cars & 1850 & 91 & 1,759 & 35.44 & 5524.53 & 35.44 & 552.6 \\
\hline * Greenhouse gas emissions & & & & & & 5524.5 \\
\hline
\end{tabular}

Table 16. Air pollutants and greenhouse gas emissions during the manufacturing process of the electric and fuel cell vehicles

\begin{tabular}{|c|c|c|}
\hline & $\begin{array}{c}\text { Air pollutants } \\
{[\mathrm{t}]} \\
\end{array}$ & $\begin{array}{c}\text { Greenhouse gas emissions } \\
{[\mathrm{t}]} \\
\end{array}$ \\
\hline Electric vehicles & 6 & 1,080 \\
\hline Fuel cell vehicles & 17 & 2,683 \\
\hline Total & 23 & 3,763 \\
\hline
\end{tabular}

\section{CONCLUSIONS}

This paper studied the conversion of the currently fossil-based thermal energy and transport sectors of a noninterconnected island in the Mediterranean into zero emission renewable-based sectors. The analysis includes both economic and environmental considerations.

Thermal energy considerations included a solar system with vacuum-tube solar collectors, a solar heat exchanger, a geothermal heat exchanger used only for water pre-heating purposes, and a radiant floor system. The building sector was a promising area for energy improvements, since a high percentage of the buildings on the island were built without proper thermal insulation. Solar thermal was found to be more expensive than the current diesel-based situation, especially in buildings with a seasonal or variable use. The renewable-based scenario became economically attractive with subsidy schemes equal to or higher than $50 \%$ of the cost. Nevertheless, the greenhouse gas emissions of the solar-thermal systems would be significantly lower than those currently generated ( $0.5 \mathrm{t} / \mathrm{a}$, compared to $3 \mathrm{t} / \mathrm{a}$ from the use of diesel).

In the transport sector, it was assumed that $70 \%$ of the existing vehicles on the island were replaced with electric cars and 30\% with fuel-cell cars. The hydrogen and electricity required were delivered from stand-alone power plants located on the island. The reference electric cars had a $24 \mathrm{kWh}$ lithium-ion battery and the hydrogen cars a reservoir capacity of $5.63 \mathrm{~kg}$ of $\mathrm{H}_{2}$. The sum of fuel and maintenance costs of the fuel-cell and electric vehicles is found to be $45 \%$ that of the current fleet. Lastly, it was seen that the avoided emissions during the use phase of the new fleet will need approximately six years to balance out the emissions of its manufacturing phase.

\section{ACKNOWLEDGEMENTS}

Fontina Petrakopoulou would like to thank the Universidad Carlos III de Madrid, the European Union's Seventh Framework Programme for research, technological development and demonstration (grant agreements no 600371 and 332028), the Ministerio de Economía y Competitividad (COFUND2014-51509) the Ministerio de Educación, cultura y Deporte (CEI-15-17) and Banco Santander.

\section{REFERENCES}

Allouhi, A., Kousksou, T., Jamil, A., Bruel, P., Mourad, Y. and Zeraouli, Y. (2015). Solar driven cooling systems: An updated review. Renewable and Sustainable Energy Reviews, 44, 159-181. https://doi.org/10.1016/j.rser.2014.12.014

Baker, P. (2011). U - values and traditional buildings In situ measurements and their comparisons to calculated values. Available at: http:/ / www.historic-scotland.gov.uk/technicalpaper10.pdf

Buildings Performance Institute Europe. (2011). Europe's buildings under the microscope - A country-by-country review of the energy performance of buildings. Available at: http://www.europeanclimate.org/documents/LR_CbC_study.pdf

Canals Casals, L., Martinez-Laserna, E., Amante García, B. and Nieto, N. (2016). Sustainability analysis of the electric vehicle use in Europe for CO2 emissions reduction. Journal of Cleaner Production, 127, 425-437. https://doi.org/10.1016/j.jclepro.2016.03.120

Caralis, G. and Emmanouilidis, G. (2009). Executive summary of the work done on Energy planning (Work package 3). Available at: http://www.aegean-energy.gr/en/pdf/executive-summary.pdf 
Devabhaktuni, V., Alam, M., Shekara Sreenadh Reddy Depuru, S., Green, R. C., Nims, D. and Near, C. (2013). Solar energy: Trends and enabling technologies. Renewable and Sustainable Energy Reviews, 19, 555-564. https://doi.org/10.1016/j.rser.2012.11.024

Eurostat. (2015). Energy price statistics - Statistics Explained. Available at: http://ec.europa.eu/eurostat/statisticsexplained/index.php/Energy_price_statistics (Accessed June 13, 2015)

Grandell, L., Lehtilä, A., Kivinen, M., Koljonen, T., Kihlman, S. and Lauri, L. S. (2016). Role of critical metals in the future markets of clean energy technologies, Renewable Energy, 95, 53-62. https://doi.org/10.1016/j.renene.2016.03.102

Grossmann, W. D., Grossmann, I. and Steininger, K. W. (2014). Solar electricity generation across large geographic areas, Part II: A Pan-American energy system based on solar. Renewable and Sustainable Energy Reviews, 32, 983 993. https://doi.org/10.1016/j.rser.2014.01.003

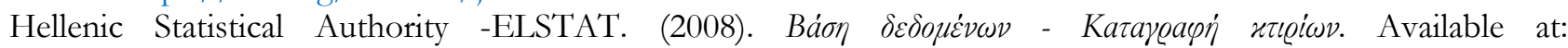
http://www.statistics.gr/portal/page/portal/ESYE/PAGE-interactive-census-map (Accessed 18 March 2015)

Hellenic Statistical Authority -ELSTAT. (2009). Digital library (ELSTAT). Available at: http://dlib.statistics.gr/portal/page/portal/ESYE/showdetails?p_id=13321502\&p_derive=book\&p_topic= 10007862 (Accessed 18 March 2015)

Hoppmann, J., Volland, J., Schmidt, T. S. and Hoffmann, V. H. (2014). The economic viability of battery storage for residential solar photovoltaic systems - A review and a simulation model. Renewable and Sustainable Energy Reviews, 39, 1101-1118. https://doi.org/10.1016/j.rser.2014.07.068

Hyundai Motor Company. (2015). ix35 Fuel cell electric vehicle. Available at: www.facebook.com/hyundaiworldwide (Accessed 28 July 2016)

IPCC. (2014). Summary for Policymakers. In Edenhofer, B. O., R. Pichs-Madruga, Y. Sokona, E. Farahani, S. Kadner, K. Seyboth, A. Adler, I. Baum, S. Brunner, P. Eickemeier and T. Z. and J. C. M. Kriemann, J. Savolainen, S. Schlömer, C. von Stechow (Eds.), Climate Change 2014, Mitigation of Climate Change. Contribution of Working Group III to the Fifth Assessment Report of the Intergovernmental Panel on Climate Change. Cambridge, United Kingdom and New York, NY, USA: Cambridge University Press.

Kamel, R. S. and Fung, A. S. (2014). Solar Systems and Their Integration with Heat Pumps: a Review. Energy and Buildings, 87, 395-412. https://doi.org/10.1016/j.enbuild.2014.11.030

Koroneos, C. and Tsarouhis, M. (2012). Exergy analysis and life cycle assessment of solar heating and cooling systems in the building environment. Journal of Cleaner Production, 32, 52-60. https://doi.org/10.1016/j.jclepro.2012.03.012

Matsakas, L., Kekos, D., Loizidou, M. and Christakopoulos, P. (2014). Utilization of household food waste for the production of ethanol at high dry material content. Biotechnology for Biofuels, 7(1), 4. https://doi.org/10.1186/1754-6834-7-4

Melaina, M. and Penev, M. (2013). Hydrogen Station Cost Estimates Comparing Hydrogen Station Cost Calculator Results with other Recent Estimates. https:/ / doi.org/10.2172/1260510

Municipality of Skyros. (2014). Personal Communication.

Nissan. (2016). 2016 Nissan Leaf.

Petrakopoulou, F. (2015a). Current energy use on Skyros: statistical, economic and environmental analyses. Technical report, Project GENERGIS (MC IEF,332028), http:/ /www.genergis.eu/publications-2

Petrakopoulou, F. (2015b). GENERGIS (Green Energy for Islands) 2012-IEF-332028, IEF Project supported by FP7. Retrieved July 24, 2015, from http://www.genergis.eu/home_en

Petrakopoulou, F. (2016). On the economics of stand-alone renewable hybrid power plants in remote regions. Energy Conversion and Management, 118, 63-74. https://doi.org/10.1016/j.enconman.2016.03.070

Petrakopoulou, F., Robinson, A. and Loizidou, M. (2016a). Exergetic analysis and dynamic simulation of a solarwind power plant with electricity storage and hydrogen generation. Journal of Cleaner Production, 113, 450-458. https://doi.org/10.1016/j.jclepro.2015.11.074

Petrakopoulou, F., Robinson, A. and Loizidou, M. (2016b). Simulation and analysis of a stand-alone solar-wind and pumped- storage hydropower plant. Energy, 96, 676-683. https://doi.org/10.1016/j.energy.2015.12.049

Pistoia, G., Dincer, I., Rosen, M. A. and Zamfirescu, C. (2010). Electric and Hybrid Vebicles. Electric and Hybrid Vebicles. Elsevier. https://doi.org/10.1016/B978-0-444-53565-8.00001-4

Sharif, M. K. A., Al-Abidi, A. A., Mat, S., Sopian, K., Ruslan, M. H., Sulaiman, M. Y. and Rosli, M. A. M. (2015). Review of the application of phase change material for heating and domestic hot water systems. Renewable and Sustainable Energy Reviews, 42, 557-568. https:// doi.org/10.1016/j.rser.2014.09.034

Shi, L. and Chew, M. Y. L. (2012). A review on sustainable design of renewable energy systems. Renewable and Sustainable Energy Reviewss, 16(1), 192-207. https://doi.org/10.1016/j.rser.2011.07.147 
Shukla, R., Sumathy, K., Erickson, P. and Gong, J. (2013). Recent advances in the solar water heating systems: A review. Renewable and Sustainable Energy Reviews, 19, 173-190. https:/ /doi.org/10.1016/j.rser.2012.10.048

Tagliaferri, C., Evangelisti, S., Acconcia, F., Domenech, T., Ekins, P., Barletta, D., ... Orlenius, J. (2016). Life cycle assessment of future electric and hybrid vehicles: A cradle-to-grave systems engineering approach. Chemical Engineering Research and Design, 112, 298-309. https://doi.org/10.1016/j.cherd.2016.07.003

United Nations. (2015). Transport for Sustainable Development the case of Inland Transport. ISBN: 978-92-1-117096-2. 